Marquette University

e-Publications@Marquette

College of Communication Faculty Research and

Publications

Communication, College of

$4-1-2010$

\title{
The World War II Patriotic Mother
}

Ana C. Garner

Marquette University, ana.garner@marquette.edu

Karen L. Slattery

Marquette University, karen.slattery@marquette.edu

Accepted version. Journalism Studies, Vol. 11, No. 2 (April 2010): 143-157. DOI. (C) 2010 Taylor \& Francis (Routledge). Used with permission. 


\title{
THE WORLD WAR II PATRIOTIC MOTHER
}

\author{
Ana C. Garner \\ Department of Journalism, Marquette University \\ Milwaukee, WI \\ Karen Slattery \\ Department of Broadcast and Electronic Communication, \\ Marquette University \\ Milwaukee, WI
}

\begin{abstract}
:
The archetypal good mother and the archetypal patriotic mother are important symbols in American culture. Both are rooted in maternal work but are separated by two conflicting assumptions. The good mother nurtures her children and protects them from harm, while the patriotic wartime mother remains silent when the government sends her child directly into harm's way. This study explores how the World War II press positioned mothers of soldiers to sacrifice their children in support of the nation's war effort. The findings point to the importance of understanding the role of archetypes in news narratives.
\end{abstract}

Keywords: archetypes, maternal work, news, patriotic mothers, world war II. 
NOT THE PUBLISHED VERSION; this is the author's final, peer-reviewed manuscript. The published version may be accessed by following the link in the citation at the bottom of the page.

\section{Introduction}

One year after the Japanese bombed Pearl Harbor, the New York Times reported that Mrs. Irene Shafer of Glendale, California won the title of "Typical Navy Mother". In return, Mrs. Shafer would spend a week visiting the Great Lakes Naval Training Station near Chicago, "inspecting kitchens, dining rooms, barracks and medical and recreational facilities..." (New York Times, December 4, 1942), She would then appear on the radio program "Meet Your Navy" in order to educate other mothers about base life for new recruits.

Naval Rear Admiral John Downes created the award, according to the Milwaukee Journal, after hearing from "anxious mothers who ask what their lads are getting to eat and whether they are required to wear their long underwear when the wind blows cold" (Milwaukee Journal, November 18, 1942). Journalists did not say whether Mrs. Shafer was anxious about her own son and what he was eating, but they reported that when she learned of the award her first thought was about her looks. She said, "I rushed right out and got a permanent. Wanted to look prety [sic] spiffy for my boys, you know" (Milwaukee Journal, December 6, 1942).

Mrs. Shafer fits the pattern of the archetypal patriotic mother, one who is caring and selfless. She supports the nation's war effort and remains silent if she suffers as a result. This American ideal traces back to the early Republic (e. 1760-1800) when mothers were expected to remain at home and raise sons who valued patriotism and participation in civic life (Kerber, 1986). We argue that the archetype of the patriotic mother emphasizes a mother's cultural role as citizen.

The patriotic mother is closely aligned with another powerful symbol, the good mother. The good mother is selfless and nurturing (Lule, 2001); her efforts are rooted in preservative love, that is, the desire to protect her child from harm (Ruddick, 1989). Thurer (1994) describes this mother-love as a "stubborn, hearty emotion" that, although subject "to environmental manipulation, seems to be a fact" (p. 6). This archetype emphasizes the cultural role of the mother qua mother.

Journalism Studies, Vol. 11, No. 2 (April 2010): pg. 143-157. DOI. This article is (C) Taylor \& Francis (Routledge) and permission has been granted for this version to appear in e-Publications@Marquette. Taylor \& Francis (Routledge) does not grant permission for this article to be further copied/distributed or hosted elsewhere without the express permission from Taylor \& Francis (Routledge). 
The archetypes share a common grounding in the maternal work of tending to the physical, emotional and social needs of the child. The critical distinction between these symbols is reflected in conflicting underlying assumptions: the archetypal good mother is expected to protect her children from harm, while the patriotic mother is expected to sacrifice her child to the nation's larger cause. She must remain stoic and silent as the government puts her child directly into harm's way.

The use of archetypes in news reporting serves the process of cultural mythmaking (Lule, 2001). Given the fact that, during peacetime, a mother's role is to protect her child from harm, we examine how the American news media drew on the archetype of the patriotic mother to position the mothers of combat soldiers to sacrifice their sons for the nation's war effort.

The study is important because war demands that mothers confront divided loyalties: to their children as children and to the nation that affords them a familiar quality of life. Certainly, other family members also cope with this problem. We focus on mothers because historical evidence suggests that they have been symbolized in U. S. cultural narratives in a way that fathers, siblings and spouses have not. We argue that the wartime press offers one such narrative from which to study the image of the patriotic mothers of soldiers and their positions vis a vis the war in situ.

The study contributes to a research tradition that examines journalism as a repository for cultural narratives (Bird \& Dardenne, 1997), allowing us to enter into a culture and a time period through news stories. The meaning of news is largely symbolic; it contains information about the cultural values, beliefs and ideals, i.e., the "normative contours of society...about right and wrong, [and] about the parameters beyond which one should not venture..." (Cohen \& Young, 1981, pp. 431). Individual news stories contribute to the ongoing narrative of human activity. While parts of the story may change, the overarching "symbolic system" remains, serving as model for and of a culture (Bird \& Dardenne, 1997, pp. 335).

Our goal is to better understand what it means to be a mother of a combat solider in wartime. While research on mothers and war not grant permission for this article to be further copied/distributed or hosted elsewhere without the express permission from Taylor \& Francis (Routledge). 
exists (e.g., de Alwis, 1998; de Volo, 2001; Elshtain, 1987; ScheperHughes, 1998), few have examined U. S. mothers of soldiers and media coverage (Cappuccio, 2006; Edwards \& Brozana, 2008; Rodino, 2005; Slattery \& Garner, 2007). Of particular interest is the work of Cappuccio (2006) and Slattery and Garner (2007). Cappuccio's (2006) study of network morning shows found that the media used mothers to justify and reinforce support for the U. S./Iraq War. Slattery and Garner (2007) reported that some mothers of soldiers publicly criticized the nation's involvement in the Iraq War and appeared to have struggled with the ideals of the patriotic mother.

This study adds to the existing scholarship by examining the image of mothers of soldiers during the first year of World War II, allowing us to discover how the wartime press helped "constitute a common culture" (Kellner, 1995, pp. 5) for these mothers. We begin by examining the symbols of the patriotic mother and the good mother. Specifically, we look at the evolution of the image of the patriotic mother in this culture and the cultural expectations of good mothers in the years leading up to the war.

\section{Symbols of Motherhood}

\section{The Patriotic Mother: mother as citizen}

The ideology of the patriotic mother is rooted in America's infancy. The early Republican mother shared her identity with her husband; she had neither vote nor voice in the public arena. She was expected to raise her children intellectually and morally, and to train her sons to be "future guardians of our beloved country" (Blackwell, 1992 , p. 11). While she was not viewed as a citizen, this role allowed a mother to "serve a political purpose" (Kerber, 1976, p, 204) by providing sorts who served the nation.

The Republican mother evolved into the Redemptive mother after the Civil War. She assumed responsibility for the moral health of the society because the market values that emerged in the Industrial Revolution were inconsistent with those embraced in the private sphere (Cutter, 2003). During the last half of the 19th century, her role in the temperance movement, the Progressive era and the 
emerging field of social work reflected her reform work in the public sphere.

Pacifists, suffragists and maternalists used their public presence to protest the proposed draft as the First World War loomed in the early $20^{\text {th }}$ century. They became targets of a government propaganda campaign when the Wilson Administration realized that mothers, in particular, could create problems for the war effort (Zeiger, 1996). The Administration began a campaign of war preparedness, enlisting support of women's groups and philanthropic organizations. The Committee of War Information, the government's wartime propaganda office, together with the film industry created movies with storylines depicting mothers as supporting their sons' willingness to go to war. Government posters portrayed patriotic mothers as joining forces with the government to send their sons into combat. Charles Dana Gibson's navy recruiting poster, for example, depicted a frail mother shaking Uncle Sam's hand with one hand and holding her son's hand with the other, Below the illustration was the quote: "Here he is, sir" (Navy Recruitment Poster); under that, and presumably directed toward the nation's mothers, another sentence added, "We need him and you too", Another poster depicted a matronly woman, arms outstretched, exhorting mothers to invest in war bonds: "Women! Help America's sons win the war" (Liberty Bond Poster).

Strict wartime censorship laws also discouraged anti-war sentiments (Zeiger, 1996), indeed, some of the women who opposed the war were convicted on grounds of espionage (Kennedy, 1999). Meanwhile, the federal government symbolically honored mothers of soldiers killed in combat, awarding them gold star medals and flags as reminders of their country's appreciation (Marvin \& Ingle, 1999). Mothers were expected to accept the honors for their sacrifice stoically and silently,

To count as a sacrifice, Cordes) (2008) has argued that a choice must be made to give up something of value in order to get or to keep something of greater value, and the loss must be viewed as regrettable. In war, for instance, soldiers' lives are sacrificed to preserve the nation. Following Cordero's line of reasoning, the archetypal patriotic mother engages in the sacrifice directly by 
encouraging her child to enlist; or indirectly by not stepping in to discourage his decision to go to war.

Evans (2007) argues that the patriotic mother accepts her loss silently, often because the culture controls her mourning. Pointing out that maternal sacrifice has had a long history, she recounted Plutarch's description of child sacrifice near Carthage to please the gods. Plutarch said the mothers were forbidden to "utter a single moan or let fall a single tear" for fear their mourning would destroy the effect of the offering (p. 18), She noted that members of societies have long honored wartime mothers in an effort to help them "develop a sense of patriotism and, if necessary, militarism" (p. 4). She studied Canadian mothers of World War I soldiers, in particular, saying that they were expected to accept their wartime losses in silence "so as not to damage the morale of others" (p. 8). These mothers were also singled out and celebrated for sacrificing multiple children to the cause.

To better understand the symbol of the patriotic mother as she appeared in the World War II press, it is useful to examine the archetype of the good mother who figured predominantly in the peacetime narratives of motherhood. Both archetypes share a commitment to maternal work. Unlike the patriotic mother, the good mother actively protects her child from harm, a quality that is valued during peacetime, but not wartime.

\section{The Good Mother: mother as mother}

The public image of the ideal woman appearing in the mass media between the First and Second World Wars was that of a housewife and mother (Rupp, 1978). She was "above all a mother with duties and functions radiating from this central role" (p. 73). In sketching her portrait, child-rearing expert Leo Kanner (1941) described her as stable, modest, self-reliant, and as one who accepts and partakes "of life's variegated menu" with good nature (p. 162); she "is a real builder of man, a solid pillar of true democracy, an object lesson in the art of preserving the integrity of family life at a time when so many families crumble and dissolve" (p. 166).

Child-raising had emerged as a public health issue around the turn of the $20^{\text {th }}$ century, largely as a result of activism by maternalists 
and middle-class American women, whose "dread of infant and maternal death" pushed them demand that physicians and the government take steps to prevent infant mortality (Ladd-Taylor, 1994, p. 19). Experts began approaching child-rearing scientifically, and while specific recommendations varied, their general counsel reflected categories that included caring for the child physically, nurturing the child cognitively and emotionally, and properly socializing the child.

Experts offered advice on eating, sleeping, elimination and the development of good habits necessary to preserve physical health (Arlitt, 1930; Thom, 1935) and prevent accidents (Gesell, 1930; Patri, 1922). They encouraged mothers to be cheerful for their child's emotional health, calling fear a "poison" (Patri, 1922, p. 19). Experts urged them to distinguish between "mother" love and "smother" love in attending to their children's needs; mothers who engaged in "smother" love ran the risk of developing clingy, dependent children (Kanner, 1941, p. 39), stunted emotionally and psychologically, and unattractive to others (Patri, 1922). Finally, socialization included rearing children of good moral character and good citizenship. Patri (1922) devoted several chapters to the importance of teaching children about their relationship to the nation, its heroes and its holidays.

Historians caution against accepting the norms prescribed by child-raising experts as those embraced by the larger society since it is unclear how closely parents followed their advice (Mechling, 1975). While we agree, we note the general themes that appeared in advice books can be found in accounts or actual child rearing. Margaret Jarman Hagood (1996), for example, studied Southern farm tenant women during the 1930's; her research suggests they, too, were concerned with their children's physical health, cognitive and emotional development, and socialization.

These themes in pre-World War II popular culture mirror the themes of maternal work later articulated by philosopher Sara Ruddick (1989) in her theory of maternal thinking. Further, she argued that "maternal practice is a 'natural resource' for peace politics" (p. 157) because it is grounded in preservative love. Tong (1993) later observed that the goals of war contradict the assumptions of maternal work since "war is about death - about canceling out the 'product(s)' 
of maternal practice" (p. 142). Together, their arguments reinforce the conflicting assumptions on which the two archetypes rest.

In summary, these archetypes are grounded in maternal efforts to develop healthy, stable, socially acceptable children. The archetypal good mother's cultural value resides in her ability to keep her children alive and raise them well. The cultural value of the patriotic mother goes beyond her maternal work. Her cultural worth is measured by her own willingness to accept the potential injury or death of her child for the sake of the nation's war effort. Against this backdrop, we turn our attention to how the World War II press positioned mothers of soldiers to make the ultimate sacrifice.

\section{Method}

We examined coverage of mothers of combat soldiers between 7 December 1941 and 30 December 1942 in the Milwaukee Journal, the New York Times, and the Albuquerque Journal. We selected these papers based on circulation size (large, medium and small) and geographic location (East, Midwest and Southwest); none were seen as national newspapers at that time. The 1941 Times' circulation was 470,161; the Milwaukee Journal's was 260,886; and the Albuquerque paper's was 19,444 (Editor and Publisher, 1941). We found 114 stories about mothers in the New York Times Historical database, 198 stories in the Albuquerque Journal using Access NewspaperARCH1VE, and 62 stories in a microfilm search of the Milwaukee Journal. Stories were analyzed if they were about mothers acting in their capacities as mothers of combat soldiers. For instance, a story about a mother who received word that her son was missing in action was included in the data pool, while a story about a soldier engaged to be married in which the mother's name was listed was not used. For this study, the term combat soldier includes members of all branches of the wartime military.

We did a textual analysis of the 374 stories looking for references and direct quotes attributed to mothers. Lule (1995) points out that analyzing story texts reveals how language and press conventions are used to create "stereotypical depictions" (p. 177). A textual analysis requires several readings in order to discover the "latent" patterns and themes contained therein (Hall, 1975). For this

Journalism Studies, Vol. 11, No. 2 (April 2010): pg. 143-157. DOI. This article is @ Taylor \& Francis (Routledge) and permission has been granted for this version to appear in e-Publications@Marquette. Taylor \& Francis (Routledge) does not grant permission for this article to be further copied/distributed or hosted elsewhere without the express permission from Taylor \& Francis (Routledge). 
study, two authors independently read and reread the stories using a constant comparative method and identified story themes in order to construct an image of mothers of combat soldiers as depicted in these newspapers. Story themes were collated and compared.

Disagreements were resolved through discussion and re-readings of the texts.

Mothers of combat soldiers appeared in story types that included: lists of dead, missing or injured soldiers; profiles of mothers; news briefs about soldier sons; prescriptive or instructional news stories; general war news; news of political events; and, patriotic essays. Quotes from mothers sometimes appeared in stories, more so in the Milwaukee Journal than in the Times or the Albuquerque Journal. Likewise, profiles of mothers of soldiers most commonly appeared in the Milwaukee Journal, rarely in the other papers. Mothers' names were most likely to appear in the lists of dead, missing or injured soldiers wherein they were named as next of kin, or in announcements of visits or as having received letters or news from their sons.

\section{The Patriotic Mother of World War H}

News narratives serve cultural mythmaking by providing symbolic cues about who and what to value and how to behave. Drawing on the symbol of the patriotic mother, these news narratives positioned the soldier's mother as citizen rather than as mother qua mother, The expectations, embedded in the symbol depicted in these stories, helped shape what she could say about the war effort and her role in it, Her success as mother was based on her willingness to sacrifice her child without complaint rather than her ability to protect her child from harm. Despite this emphasis, she was still expected to continue her maternal work but in a limited way.

\section{Maternal Work}

Much of the work of the patriotic mother described in these narratives paralleled the work of the archetypal good mother. During peacetime, good mothers scrutinize the environment so that they can head off danger to their children before and when it arises (Gesell, 1930; Langdon, 1946: Path 1922). These news narratives suggested

Journalism Studies, Vol. 11, No. 2 (April 2010): pg. 143-157. DOI. This article is @ Taylor \& Francis (Routledge) and permission has been granted for this version to appear in e-Publications@Marquette. Taylor \& Francis (Routledge) does not grant permission for this article to be further copied/distributed or hosted elsewhere without the express permission from Taylor \& Francis (Routledge). 
that mothers did not stop scrutinizing the environment just because the soldiers were over age 18 when they enlisted or were drafted. Keeping tabs on her soldier son appeared as a routine part of her duty. One news story, for example, reported that "'Ma' follow[ed] the military service of her sons with the same keen interest she took in the football careers of four of them" (Milwaukee Journal, August, 22, 1942). Letters, wires, phone calls, broadcasts, the local newspaper and visits from the military were the primary means by which mothers learned their children's whereabouts. One mother, for example, sent her daughter to Milwaukee Journal to ask about the fate of her son who was at Pearl Harbor during the Japanese attack (Milwaukee Journal, January 10, 1942). Some Albuquerque mothers were described as disappointed when a speech given by a sergeant did not contain "tidings of their boys" who were fighting in the Philippines (Albuquerque Journal, December 30, 1942). Overall, the press depicted the mothers' scrutinizing behavior as normal.

Stories also told of mothers' efforts to offer physical protection for their children where they could. One mother picked cotton for parachutes (Milwaukee Journal, October 10, 1942). Another with "two sons in the service" said she wanted "to work at something which will have me actively supplying them with the necessary weapons to drive off the invader. ... I don't care how dangerous it is, but our country is at war and we all have to do our bit" (New York Times, December 30, 1941). Another gave six pints of blood to avoid feeling "so guilty for not doing anything" (Milwaukee Journal, December 30, 1942). These depictions illustrated the extra lengths some mothers would take for their sons and the war effort.

According to the child-rearing experts of the 1920s and 1930s, society judged a mother's success on whether the child was properly socialized into the community. The wartime mothers could no longer actively socialize their children, but the press narratives gave them opportunities to tell the nation that they had raised good citizens. Sons were described being on the honor roll and having the "tremendous capacity for hard work" (Milwaukee Journal, February 4, 1942). Sons reportedly sent money home to their mothers for Christmas (New York Times, December 9, 1942) and to support local charities (New York Times, December 10, 1942), They were good soldiers who knew "what to leave out" in letters home (Albuquerque Journal, December 27, not grant permission for this article to be further copied/distributed or hosted elsewhere without the express permission from Taylor \& Francis (Routledge). 
1942), and were heroes who wanted to enlist (New York Times, July 1 , 1942; New York Times, July 23, 1942) and who saved the lives of others (New York Times, December 22, 1942). Together, these stories offer evidence that the mothers of soldiers behaved in ways consistent with the concept of maternal work common to both archetypes.

In these stories, however, maternal work that was normally done in the private sphere became public; mothers were depicted as caring for the nation's children and their families. We saw this in news narratives about mothers who knitted hats and mittens for soldiers (Milwaukee Journal, December 28, 1942); opened their homes to and fed sailors passing through (Milwaukee Journal, April 24, 1942); painted portraits of soldiers which they in turn could send home to their mothers (Milwaukee Journal, April 19, 1942); and, finally, shared letters from the front with other anxious parents (Milwaukee Journal, July 9,1942$)$.

Further, news narratives indicated that maternal work was often institutionalized in that it was done within groups or organizations; mothers forfeited control over how and when much of the work was done. For example, mothers reportedly formed "Button Brigades" or mending groups such as the "Mending Mothers of Miles" who took care of the "valet problems" of the soldiers at Fort Miles. The narratives stated that mothers would "darn his socks, mend his 'unmentionables' and iron his handkerchiefs" (New York Times, November 16, 1942). But, in some instances, the military assumed control of the work and notified mothers of such. In one story, the press reported that the military told mothers they no longer needed to "worry about their darlings in torn or buttonless uniforms or in undarned socks" as the sons at Fort Wadsworth could learn to darn or sew "under expert tutelage" (New York Times, June 23, 1942). Other stories depicted mothers as working with the Military to convince other mothers that their son's maternal needs were being met. The story about the Mrs. Shafer, the "typical Navy mother", referenced earlier offers an example.

\section{Training the Wartime Mother}

Literature about "good mothering" abounded during peacetime. During wartime, the press served as a repository for training material

Journalism Studies, Vol. 11, No. 2 (April 2010): pg. 143-157. DOI. This article is @ Taylor \& Francis (Routledge) and permission has been granted for this version to appear in e-Publications@ Marquette. Taylor \& Francis (Routledge) does not grant permission for this article to be further copied/distributed or hosted elsewhere without the express permission from Taylor \& Francis (Routledge). 
about the requirements of "patriotic mothering". In some stories, mothers were told how to behave around their soldier sons by the military, other mothers or wartime journalists. One article, for instance, told of a decorated soldier and his mother who collaborated on recommendations for creating an "ideal furlough" (New York Times, December 24, 1942). Cautions included not talking too much, telling him about other soldiers who received promotions or showing him off to friends. The last tip reflected child-rearing advice by Langdon (1946) who told mothers to avoid embarrassing their children by showing them off.

News stories also instructed mothers on effective means of communicating with their children in the service. One advice columnist urged divorced parents to put aside their differences and lift their son's spirit with a letter from home. She added, "Whether or not you have been with your sons lately, do this kindly act for the boys you brought into this world!" (Milwaukee Journal, February 27, 1942). Another story instructed moms on how to post their letters to Australia for speedy delivery to their soldier sons (Milwaukee Journal, April 2, 1942) and another gave them a lesson in Army slang so they could understand their sons' new language (Albuquerque Journal, October $18,1942)$.

In summary, these stories normalized the mother's need to continue maternal work despite the absence of her child, and the culture's efforts to train her to assume her patriotic role. At the same time, the stories reflected a larger narrative that emphasized her sacrifice.

\section{Maternal Sacrifice}

The World War $\mathrm{H}$ news narratives transformed what would have been an unacceptable loss during peacetime into an acceptable but regrettable loss during wartime. They advanced the idea that the mothers' sacrifices were worthy and tolerable. This was accomplished through the voices of politicians, ministers, wives of soldiers and diplomats who all called attention to these sacrifices. For instance, one story reported that Bishop Joseph Hurley told the mothers of the National Council of Catholic Women that their sons were "fighting a. just war...for a sacred cause" (Milwaukee Journal, April 23, 1942). In

Journalism Studies, Vol. 11, No. 2 (April 2010): pg. 143-157. DOI. This article is (C) Taylor \& Francis (Routledge) and permission has been granted for this version to appear in e-Publications@Marquette. Taylor \& Francis (Routledge) does not grant permission for this article to be further copied/distributed or hosted elsewhere without the express permission from Taylor \& Francis (Routledge). 
another, Dr. Norman Vincent Peale said that Christ would fill the emptiness in their hearts (New York Times, June 15, 1942). Some stories implicitly encouraged mothers to give more than one son. The Milwaukee Journal, for example, repeatedly featured mothers who gave multiple children to the service on the front page, highlighting their "proud" contributions (Milwaukee Journal, April 27, 1942; Milwaukee Journal, August 22, 1942).

Mothers themselves helped to mark their sacrifice as worthy. Stories told of military mothers who made blue star service flags for other mothers to hang in their windows as public statements of maternal sacrifice (Milwaukee Journal, February 3, 1942). Mothers were also depicted as supporting the war effort (Milwaukee Journal, October 5, 1942; New York Times, July 25, 1942), even in the face of a son's death. Said one mother, "....[N]ow he is gone and as soon as I get my strength back I will try to carry on where he left off. I will buy what defense bonds I can out of his insurance money and sew for the Red Cross" (Milwaukee Journal, February 8, 1942).

In other stories, mothers spoke with pride about the sacrifice required by war. For instance, in an election rally speech, one mother reportedly stated "I have my worries over my four men... but I wouldn't have it otherwise. ...It is a wonderful country, and I should be sorry, indeed, if my husband and sons did not assume their obligations to defend their country against aggression" (New York Times, October 23, 1942). Mothers were also depicted as encouraging sons to enlist in the war effort. '"I don't believe in boys waiting to be drafted', said Mrs. Alberte. 'They should enlist if the country needs them"' (Milwaukee Journal, May 3, 1942). One mother took her pride a step further, telling one reporter, "I'm not a civilian, but a real soldier" (Albuquerque Journal, April 23, 1942).

News narratives further reinforced the acceptance of sacrifice by reporting on rewards and recognition offer to mothers whose sons died in combat. Symbolic support of the military and government became visible when mothers received gold star flags when they lost their sons (Milwaukee Journal, December 18, 1942) or heard public eulogies. In one story, a mother listened as the President eulogized her son who has just lost his life (Milwaukee Journal, November 30, 1942). Other honors included opportunities to sponsor seaplane tenders (Milwaukee

Journalism Studies, Vol. 11, No. 2 (April 2010): pg. 143-157. DOI. This article is @ Taylor \& Francis (Routledge) and permission has been granted for this version to appear in e-Publications@Marquette. Taylor \& Francis (Routledge) does not grant permission for this article to be further copied/distributed or hosted elsewhere without the express permission from Taylor \& Francis (Routledge). 
NOT THE PUBLISHED VERSION; this is the author's final, peer-reviewed manuscript. The published version may be accessed by following the link in the citation at the bottom of the page.

Journal, May 5, 1942b) or ships (Albuquerque Journal, October 19, 1942 ) or unveil an honor roll (New York Times, July 5, 1942).

Members of foreign and U.S. military recognized mothers of combat soldiers on Mother's Day and assured them that their sons were being well cared for (Milwaukee Journal, May 10, 1942b). The wife of a U.S. diplomat praised New Mexico mothers as "brave...patient and uncomplaining" (Albuquerque Journal, August 20, 1942).

Recognition of maternal sacrifice came from the many civic organizations. The "American mothers' committee of the Gold Rule Foundation", for example, named a mother of 13 children, some of whom were in the service, as "the American mother of 1942". She would serve as "a representative of the best there is in all motherhood" (Milwaukee Journal, April 7, 1942). Clubs, libraries, and women's organizations held teas and luncheons to honor local mothers of combat soldiers (Milwaukee Journal, May 20, 1942).

Finally, praise also came from the press itself. The narrator's voice appeared in some stories printed in the Milwaukee Journal and the Albuquerque Journal. For instance, a journalist described one mother as "proud, and rightly so, of her contribution to Uncle Sam's war program" (Milwaukee Journal, March 29, 1942). Together, these narratives, offer examples of efforts both by the public and mothers themselves to make the maternal sacrifice acceptable. These stories form a metanarrative that tells the combat soldier's mother that her sacrifice, while regrettable, is honorable and justifiable because it serves a greater cause. The narrative tells the mother that her loss is culturally sanctioned.

Conversely, mothers were chastised if they articulated personal anxieties, dreads or fears, This sentiment was expressed in the news story about one mother, who reportedly argued that a mother had a duty to keep her soldier son's "spirits high", stating that "some of these mothers, they cry all over their boys when the boys leave. The boys actually get sick sometimes because of it. If everybody was a crybaby we'd never win the war. I wish some mothers would do more praying for their boys and less moaning" (Milwaukee Journal, May 3, 1942). These types of comments served to reinforce the image of the patriotic mother's stoicism and silence. They also functioned to set the image of the bad mother (Lule, 2001).

Journalism Studies, Vol. 11, No. 2 (April 2010): pg. 143-157. DOI. This article is @ Taylor \& Francis (Routledge) and permission has been granted for this version to appear in e-Publications@Marquette. Taylor \& Francis (Routledge) does not grant permission for this article to be further copied/distributed or hosted elsewhere without the express permission from Taylor \& Francis (Routledge). 
In some stories, mothers were implicitly criticized for attitudes and behaviors that could be viewed out of line with the nation's war effort. For example, a son in the Army thanked his mother in a Mother's Day letter for not trying to "tie me to your apron strings" (Milwaukee Journal, May 10, 1942a). Other organizations, such as the American Legion Auxiliary, criticized mothers who resisted lowering the draft age (New York Times, November 6, 1942). Mothers of soldiers were also criticized for behaviors that might create further problems for a nation at war. They were singled out in a New York Times story for their son's "picky" eating habits and the problems it caused the military (New York Times, October 20, 1942). The Milwaukee Journal printed a similar story, reporting that the food consultant to the Secretary of War "attributed failure of some young men to pass army physical tests to finicky appetites, and blamed their mothers for not supplying them with the proper diet" (Milwaukee Journal, March 13, 1942), The criticism suggests some mothers failed in their duty to raise sons ready to serve the nation and the stories are illustrative of how the media constructed and then reinforced the archetype of the patriotic mother.

\section{Cracks in the Façade}

Despite the overwhelmingly positive, uplifting portrait of the patriotic good mother, cracks appeared in that image in some of the narratives. Most stories included little indication of how the mothers might feel privately, but a few stories included instances in which the mothers' raw anxiety and fear showed through. For example, several stories described mothers as continuing their housework and other domestic duties as means of coping. One mother said, "Even if I have to work hard. I got lots of patience. The boys' going away is like sickness. You have to take it" (Milwaukee Journal, August 22, 1942). Other stories depicted mothers as in denial at the news that their sons were dead. For example, one mother said, "Maybe he will turn up somewhere" (New York Times, August 11, 1942), while another said she expected their missing son to show up "someday before long" (New York Times, August 12, 1942). A few news stories hinted at the mother's internal struggles over a son's death. "He was all I had" said one mother who lost her only child (Milwaukee Journal, February 8 , 1942). Another mother said she had asked her son to wait "until you're called" but that "she could not dissuade him" (Milwaukee permission has been granted for this version to appear in e-Publications@Marquette. Taylor \& Francis (Routledge) does not grant permission for this article to be further copied/distributed or hosted elsewhere without the express permission from Taylor \& Francis (Routledge). 
Journal, February 27, 1942). Other news stories conveyed the toll a son's absence had on a mother's health or even life. For example, seeing a picture of her soldier son in a magazine was said to help a mother walk again (Milwaukee Journal, May 5, 1942a). Another mother reportedly collapsed and died as she sat at the radio waiting for news about her son whose ship had been torpedoed (Milwaukee Journal, November 30,1942) and yet another committed suicide (New York Times, December 14, 1941). While few in number, these stories point to the fact that some mothers, indeed, struggled with their sacrifice.

In summary, the WWII news stories as cultural narratives provide a portrait of the ideal patriotic mother during times of war, highlighting her values and behaviors, as well as limitations on what she could say or do. The mother of the combat soldier in these narratives was caring, stoic and supportive of her country. She was portrayed as willing to sacrifice her own self-interest and that of her child in the interest of others. The ideal patriotic mother did not bend to the grief, the hopelessness or the despair that Ruddick's theory suggests would logically flow out of the maternal work and attentive love. In fact, through these narratives, the culture discouraged anything other than wholehearted support for her sacrifice and her support for the nation' war effort.

\section{Conclusions}

Our analysis revealed that the World War II press helped socialize mothers of soldiers into their wartime roles, lending support to the work of media and cultural theorists who argue that cultural institutions play an important part in socialization (Bird \& Dardenne, 1997; Herman \& Chompsky, 1988; Lule, 2001). The wartime press emphasized the mother's role as citizen by drawing on the archetype of the patriotic mother. This archetype served to refrarne her position within wartime society, while also serving as a guide for proper conduct. The press portrayed the wartime mother as the defender of her country rather than of her child, positioning her as willing to accept the sacrifice of her son for the nation's sake.

The cultural use of the wartime symbol of the patriotic mother reflected a shift in maternal ideology. The shift was subtle because it

Journalism Studies, Vol. 11, No. 2 (April 2010): pg. 143-157. DOI. This article is @ Taylor \& Francis (Routledge) and permission has been granted for this version to appear in e-Publications@Marquette. Taylor \& Francis (Routledge) does not grant permission for this article to be further copied/distributed or hosted elsewhere without the express permission from Taylor \& Francis (Routledge). 
remained within the larger, familiar context of motherhood. Yet, its implication was profound. The patriotic mother moved the task of maternal work from her private sphere to the public arena where she shared her work with the military and the government, where she cared for all of the nation's soldiers, not just her own. Most importantly, she was valued for her willingness to look the other way while her child faced injury or death. Her success as a patriotic mother depended on how she responded to her loss, for what she said as well as what she did not say. The news narratives presented the mother's adaptation to her role as normative. The transition appeared seamless.

In normalizing this image of the wartime mother, then, the press also functioned to normalize the loss of children, losses that would be unthinkable during peacetime. It did so by recording recognition of these losses as worthy and appropriate, symbolized by the standards of gold stars and the American flag. The efforts to normalize the human cost of maternal sacrifice during wartime are especially striking when contrasted with the stories told of a mother who committed suicide and another who collapsed and died after hearing news of her son's death. While rare, these stories offer insights into the feelings mothers may have experienced beyond support for the nation's war effort, but which, overall, appeared beyond the gaze of the World War 11 news media.

These latter stories maybe viewed as exceptions to the rule regarding the way patriotic mothers should think and feel.

Alternatively, they can be read as evidence that the historical record of mothers' response to the war, as presented in the press, may have been quite incomplete. Press coverage offered only the briefest look into what Emily Dickenson called "the interiority of the heart", or private, personal feelings and emotions of mothers as mothers. The feelings of the mothers as citizens may have reflected their private feelings as mothers, but we do not know for sure.

Ruddick (1989) argued that there is a contradiction between "maternal and military aims" (p. 157) and that, we believe, rings true. However, maternal work occurs in specific historical and political circumstances, and what may be viewed as appropriate and desirable in one context, e.g., an all out defensive war such as World War II, may not be so in another. The World War $\mathrm{H}$ mothers appearing in 
these stories may have firmly and genuinely believed that they had no choice but to act in concert with the rest of the nation in defending the democratic way of life here and abroad. In addition, while the press was complicit in socializing wartime mothers, the historical position of the press during this conflict must also be considered. Newspaper editors and publishers often worked with limited wartime staffs because their colleagues had been drafted. Some had their own children fighting overseas and were reluctant to publish stories that could be viewed as threatening to the country's war effort. With millions of sons in combat, it is unlikely that mothers would have had tolerance for news coverage that could be interpreted as offering comfort to the enemy.

At the same time, we know that the press image of the wartime mothers of soldiers has shifted since the Second World War. Mothers of United States soldiers in the U. S./Iraq war, for example, were allowed by the press to openly express negative feelings about the nation's engagement in the conflict. While many mothers expressed support for the war, others made it clear that they supported their children, but not the nation's war effort.

There may be several reasons for the difference in press portrayals. The variations in maternal images between these two wars may be a function of how wars are reported in different historical periods, how cultures perceive women's roles in these periods, or the reflection of emerging women's voices. The differences warrant further investigation, Lule (2001) argues that humans are storytellers and societies use stories to challenge, to entertain, to inform and to instruct. Viewed this way, news stories are more than strings of facts. They draw on archetypes to offer exemplars of appropriate behavior in a culture. Archetypes are powerful symbols that can be used to mobilize citizens. As we continue to seek to understand what it means to be the mother of a soldier during wartime, and the impact of war on a culture, the use of archetypes must be considered. 
NOT THE PUBLISHED VERSION; this is the author's final, peer-reviewed manuscript. The published version may be accessed by following the link in the citation at the bottom of the page.

\section{REFERENCES}

1. Albuquerque Journal (1942) "New Mexico War Mothers Need No Urge to Duty, says Mrs. Patrick J. Hurley", 20 August, n.p. Available: Access NewspaperARCHIVE database.

2. Albuquerque Journal (1942) "How to Write to Him in His Own Language", 18 October, n.p. Available: Access NewspaperARCHIVE database.

3. Albuquerque Journal (1942) "Three Survivors of The Lexington See Mother Christen Navy Ship With Water", 19 October, n.p. Available: Access NewspaperARCHIVE database.

4. Albuquerque Journal (1942) "Wife of Soldier Missing in Bataan", 3 November, n.p. Available: Access NewspaperARCHIVE database.

5. Albuquerque Journal (1942) "Keep Turning Out the Stuff', 27 December, n.p. Available: Access NewspaperARCHIVE database.

6. Albuquerque Journal (1942) "Club Re-elects Mrs. H.W. Meyer", 30 December, n.p. Available: Access NewspaperARCHIVE database.

7. Arlitt, Ada (1931) The Child From One to Twelve: psychology for parents, New York: McGraw-Hill Book Company, Inc.

8. Bird, Elizabeth and Dardenne, Robert (1997) "Myth, Chronicle and Story: exploring the narrative qualities of news", in Dan Berkowitz (Ed), Social Meanings of News, Thousand Oaks: Sage, pp. 333-350.

9. Blackwell, Marilyn S. (1992) "The Republican Vision of Mary Palmer Tyler", Journal of the Early Republic 12, pp. 11-35.

10. Cappuccio, Sondra N. (2006) "Mothers of Soldiers and the Iraq War: justification through breakfast shows on $\mathrm{ABC}, \mathrm{CBS}$, and NBC", Women \& Language 29(1), pp. 3-9.

11. Cohen. Stanley and Young, Jock (1981) The Manufacture of News, Beverly Hills: Sage.

12. Cordero, Ronald A. (2008) "Human Sacrifice Today", Journal of Value Inquiry, 42, pp. 203-216.

Journalism Studies, Vol. 11, No. 2 (April 2010): pg. 143-157. DOI. This article is @ Taylor \& Francis (Routledge) and permission has been granted for this version to appear in e-Publications@Marquette. Taylor \& Francis (Routledge) does not grant permission for this article to be further copied/distributed or hosted elsewhere without the express permission from Taylor \& Francis (Routledge). 
NOT THE PUBLISHED VERSION; this is the author's final, peer-reviewed manuscript. The published version may be accessed by following the link in the citation at the bottom of the page.

13. Cutter, Barbara (2003) Domestic Devils, Battlefield Angels: the radicalism of American womanhood, DeKalb, IL: Northern Illinois University Press.

14. De Alwis, Malathi (1998) "Moral Mothers and Stalwart Sons: reading binaries in a time of war", in: Lois A. Lorentzen and Jennifer Turpin (Eds), The Women and War Reader, New York: New York University Press, pp. 254-271.

15. De Volo, Lorraine B. (1998) "Drafting Motherhood: maternal imagery and organizations in the United States and Nicaragua", in: Lois A. Lorentzen and Jennifer Turpin (Eds), The Women and War Reader, New York: New York University Press, pp. 240-253.

16. Edwards, Janis L. and Brozana, Amanda L. (2008) "Gendering Anti-War Rhetoric: Cindy Sheehan's symbolic motherhood", Journal of the Northwest Communication Association, 37, pp. 78-102.

17. Egan, Leo (1942) "Bennett Pledges Care for Soldiers", New York Times, 23 October, n.p. Available: ProQuest Historical Newspapers The New York Times (1851-2004) database.

18. Elshtain, Jean B. (1987) Women and War, New York: Basic Books.

19. Evans, Suzanne (2007) Mothers of Heroes Mothers of Martyrs: World War I and the politics of grief Montreal and Kingston: McGill-Queen's University Press.

20. Gesell, Arnold (1930) The Guidance of Mental Growth in Infant and Child, NY: The Macmillan Company.

21. Griggs, lone Q. (1942) "Divorced Parents, Do You Write to Your Soldier Sons?", Milwaukee Journal, 27 February, p. 2.

22. Hagood, Margaret J. (1996, 1939) Mothers of the South: portraiture of the while tenant hum woman, Charlottesville, VA: University Press of Virginia.

23. Hall, Stuart (1975) "Introduction", in: Anthony Charles H. Smith, Elizabeth Immirzi and Trevor Blackwell, Paper Voices: the popular press and social change 1935-1965, Totowa, NJ: Rowman and Littlefield, pp. 1124.

Journalism Studies, Vol. 11, No. 2 (April 2010): pg. 143-157. DOI. This article is (C) Taylor \& Francis (Routledge) and permission has been granted for this version to appear in e-Publications@Marquette. Taylor \& Francis (Routledge) does not grant permission for this article to be further copied/distributed or hosted elsewhere without the express permission from Taylor \& Francis (Routledge). 
NOT THE PUBLISHED VERSION; this is the author's final, peer-reviewed manuscript. The published version may be accessed by following the link in the citation at the bottom of the page.

24. Herman, Edward and Chomsky, Noam (1988) Manufacturing Consent: the political economy qf the mass media, New York: Pantheon Books.

25. Kanner, Leo (1941) In Defense of Mothers: how to bring up children in spite of the more zealous psychologists, Springfield, IL: Bannerstone House.

26. Kellner, Douglas (1995) "Cultural Studies, Multiculturalism and Media Culture", in: Gail Dines and Jean M. Humez (Eds), Gender, Race and Class in Medta, London: Sage, pp 9-20.

27. Kennedy, Kathleen (1999) Disloyal Mothers and Scurrilous Citizens: women and subversion during World War I, Bloomington: Indiana University Press.

28. Kerber, Linda (1976) "The Republican Mother: women and the Enlightenment-an American perspective", American Quarterly, 28(2), pp.187-205.

29. Kerber, Linda (1986) Women of the Republic: intellect and ideology in revolutionary America, New York: Norton.

30. Ladd-Taylor, Molly (1994) Mother-Work: women, child welfare, and the stale, 1890-1930, Urbana IL: University of Illinois Press.

31. Langdon, Grace (1946, 1931) Home Guidance for Young Children: a parents' handbook, NY: The John Day Company.

32. Liberty Bond Poster, http://lewb2.1oc.govkgii-biniquery, accessed 9 December 2008.

33. Lute, Jack (1995) "The Rape of Mike Tyson: race, the press and symbolic types", Critical Studies in Mass Communication 12, pp. 76-195.

34. Jack (2001) Daily News, External Stories: the mythological role of journalism, New York: Guilford.

35. Marvin, Carolyn and Ingle, David (1999) Blood Sacrifice and the Nation: totem rituals and the American flag, New York: Cambridge University Press.

36. Mechling, Jay (1975) "Advice to Historians on Advice to Mothers", Journal of Social History 9, pp. 44-63.

Journalism Studies, Vol. 11, No. 2 (April 2010): pg. 143-157. DOI. This article is (C) Taylor \& Francis (Routledge) and permission has been granted for this version to appear in e-Publications@Marquette. Taylor \& Francis (Routledge) does not grant permission for this article to be further copied/distributed or hosted elsewhere without the express permission from Taylor \& Francis (Routledge). 
NOT THE PUBLISHED VERSION; this is the author's final, peer-reviewed manuscript. The published version may be accessed by following the link in the citation at the bottom of the page.

37. Milwaukee Journal (1942) "Mother Keeps Hope for Son Feared Killed as Utah Sank", 10 January, n.p.

38. Milwaukee Journal (1942) "Makes Flags for Mothers of Navy Sons", [photograph] 3 February, P.

39. Milwaukee Journal (1942) "Proud Couple Describe Their Boy, the General", 4 February, p. 1.

40. Milwaukee Journal (1942) "Told of Death in Philippine", 8 February, p. 3.

41. Milwaukee Journal (1942) "Sailor Lost, Mother Told", 27 February, p. 1.

42. Milwaukee Journal (1942) "Mother to Blame if Soldier is Finicky Eater, Says She", 13 March, p. 12.

43. Milwaukee Journal (1942) "She Gives Five Sons to America's War Effort" [photograph], 29 March, p. 1.

44. Milwaukee Journal (1942) "How to Speed Your Letters to Boys Posted in Australia", 2 April, p. 4.

45. Milwaukee Journal (1942) "American Mother Title for '42 Goes to a Mother of $13 ", 7$ April, p. 8.

46. Milwaukee Journal (1942) "Mother of a Soldier, Artist is Gladdening Other Mothers", 19 April, P. 1.

47. Milwaukee Journal (1942) "War Mothers Pray at Shrine", 23 April, p. 14.

48. Milwaukee Journal (1942) "Sailor's Mother Here Gains Wide Fame as Hostess", 24 April, p. 5.

49. Milwaukee Journal (1942) "Four Star Mother Expects Son Will Join Army Soon", 27 April, p. 12.

50. Milwaukee Journal (1942) "Mother of 11. One in Army, Helps Morale on Home Front", 3 May, p 15.

51. Milwaukee Journal (1942a) "Magazine Picture of Soldier Son Helps Stricken Mother", 5 May, p. 16.

Journalism Studies, Vol. 11, No. 2 (April 2010): pg. 143-157. DOI. This article is (C) Taylor \& Francis (Routledge) and permission has been granted for this version to appear in e-Publications@Marquette. Taylor \& Francis (Routledge) does not grant permission for this article to be further copied/distributed or hosted elsewhere without the express permission from Taylor \& Francis (Routledge). 
NOT THE PUBLISHED VERSION; this is the author's final, peer-reviewed manuscript. The published version may be accessed by following the link in the citation at the bottom of the page.

52. Milwaukee Journal (1942b) "Mother Who Lost Three Sons at Pearl Harbor is Honored", 5 May, p. 6.

53. Milwaukee Journal (1942a) "A Mother's Day Letter From a Milwaukee Son in the Army", 10 May, p. 1.

54. Milwaukee Journal (1942b) "Mother - It's Her Day Today", 10 May, p. 3.

55. Milwaukee Journal (1942) "War Mothers to be Guests at Wauwatosa Tea", 20 May, p. 5.

56. Milwaukee Journal (1942) "Letters Oust Card Playing as Thrill for Navy Parents", 9 July, p. 1.

57. Milwaukee Journal (1942) "Give Five Sons Each to U.S., These Widows Don't Fret", 22 August, p. 1.

58. Milwaukee Journal (1942) "Buy War Bonds, Says Mother of Sailor Killed in Last War", 5 October, p. 3.

59. Milwaukee Journal (1942) "Mother of Missing Airman Helps Pick Cotton for Chutes", 10 October, p. 3.

60. Milwaukee Journal (1942) "Wanted, Typical Navy Mother, To See Great Lakes", 18 November, p. 17.

61. Milwaukee Journal (1942) "Mother Seeking News About Son Dies at Radio", 30 November, p.

62. Milwaukee Journal (1942) "'Typical Navy Mother' Offers Love Advice to Sailors", 6 December, p. 2.

63. Milwaukee Journal (1942) "Hear Praise for Hero Sons: parents' pride softens grief", 18 December, p. 20.

64. Milwaukee Journal (1942) "Mother of Four Sons in Service Gives Her Time to Red Cross", 28 December, p. 18.

65. Milwaukee Journal (1942) "She Gives 6" Pint of Blood", 30 December, p. 1.

66. Navy Recruitment Poster

http:Icweb2.loc.gov/cgibin/query/D?ils:3:./temp/ ppaFMI ::, accessed 9 December 2008.

Journalism Studies, Vol. 11, No. 2 (April 2010): pg. 143-157. DOI. This article is (C) Taylor \& Francis (Routledge) and permission has been granted for this version to appear in e-Publications@Marquette. Taylor \& Francis (Routledge) does not grant permission for this article to be further copied/distributed or hosted elsewhere without the express permission from Taylor \& Francis (Routledge). 
NOT THE PUBLISHED VERSION; this is the author's final, peer-reviewed manuscript. The published version may be accessed by following the link in the citation at the bottom of the page.

67. New York Times (1942) "Faith Urged on Soldiers", 15 June, n.p. Available: ProQuest Historical Newspapers The New York Times (1851-2004) database.

68. New York Times (1942) "Soldiers Kept Neat by 'Button Brigade' A.W.V.S. Unit Also Teaches Men to Darn and Men". 23 June, n.p. Available: ProQuest Historical Newspapers The New York Times (1851-2004) database.

69. New York Times (1942) "Status Quo Urged Till War is Ended", 5 July, n.p. Available: ProQuest Historical Newspapers The New York Times (18512004) database.

70. New York Times (1942) "Family is Thrilled By Cullen's Exploit", 16 July, n.p. Available: ProQuest Historical Newspapers The New York Times (1851-2004) database.

71. New York Times (1942) "Dwyer Wounded at Midway", 23 July, n.p. Available: ProQuest Historical Newspapers The New York Times (18512004) database.

72. New York Times (1942) "War Bond Drive Set for September", 25 July, n.p. Available: ProQuest Historical Newspapers The New York Times (18512004) database.

73. New York Times (1942) "77 Men of the Army Missing in Action", 11 August, n.p. Available: ProQuest Historical Newspapers The New York Times (1851-2004) database.

74. New York Times (1942) "86 More Soldiers Missing at Sea", 12 August, n.p. Available: ProQuest Historical Newspapers The New York Times (18512004) database.

75. New York Times (1942) "Predicts New Diet as One War Result", 20 October, n.p. Available: ProQuest Historical Newspapers The New York Times (1851-2004) database.

76. New York Times (1942) "Legion Women Oppose 18-19 Draft Curbs: urge end of interference with military", 6 November, n.p. Available: ProQuest Historical Newspapers The New York Times (1851-2004) database.

Journalism Studies, Vol. 11, No. 2 (April 2010): pg. 143-157. DOI. This article is (C) Taylor \& Francis (Routledge) and permission has been granted for this version to appear in e-Publications@Marquette. Taylor \& Francis (Routledge) does not grant permission for this article to be further copied/distributed or hosted elsewhere without the express permission from Taylor \& Francis (Routledge). 
NOT THE PUBLISHED VERSION; this is the author's final, peer-reviewed manuscript. The published version may be accessed by following the link in the citation at the bottom of the page.

77. New York Times (1942) "To Sew for Service Men: women's club in Lewes, Del., votes to give free 'valet service"', 16 November, n.p. Available: ProQuest Historical Newspapers The New York Times (1851-2004) database.

78. New York Times (1942) "The 'Typical Navy Mother'", 4 December, n.p. Available: ProQuest Historical Newspapers The New York Times (18512004) database.

79. New York Times (1942) "Thrifty Soldier Killed in Action", 9 December, n.p. Available: ProQuest Historical Newspapers The New York Times (18512004) database.

80. New York Times (1942) "3 Soldiers Abroad Give for Neediest", 10 December, n.p. Available: ProQuest Historical Newspapers The New York Times (1851-2004) database.

81. New York Times (1941) "War Brings Her Suicide: German-born mother of army private ends life", 14 December, n.p. Available: ProQuest Historical Newspapers The New York Times (1851-2004) database.

82. New York Times (1942) "Prisoners Listed as in Philippines", 22 December, n.p. Available: ProQuest Historical Newspapers The New York Times (1851-2004) database.

83. New York Times (1942) "What Fighting Men Like When Home on Furlough", 24 December, n.p. Available: ProQuest Historical Newspapers The New York Times (1851-2004) database.

84. New York Times (1942) "War Roles Sought by Jersey Women", 30 December, n.p., Available: ProQuest Historical Newspapers The New York Times (1851-2004) database.

85. Patri, Angelo (1922) Child Training, New York; D. Appleton and Company.

86. Rodino, Michele (2005) "War Mothering", Feminist Media Studies 5(3), pp. 380-385.

87. Ruddick, Sara (1989) Maternal Thinking: toward a politics of peace, Boston: Beacon Press.

88. Rupp, Leila J. (1978) Mobilizing Women for War, Princeton: Princeton University Press.

Journalism Studies, Vol. 11, No. 2 (April 2010): pg. 143-157. DOI. This article is @ Taylor \& Francis (Routledge) and permission has been granted for this version to appear in e-Publications@Marquette. Taylor \& Francis (Routledge) does not grant permission for this article to be further copied/distributed or hosted elsewhere without the express permission from Taylor \& Francis (Routledge). 
NOT THE PUBLISHED VERSION; this is the author's final, peer-reviewed manuscript. The published version may be accessed by following the link in the citation at the bottom of the page.

89. Scheper-Hughes, Nancy (1998) "Maternal Thinking and the Politics of War", in: Lois A. Lorentzen. and Jennifer Turpin (Eds), The Women and War Reader, New York: New York University Press, pp. 227-233.

90. Slattery, Karen and Garner, Ana (2007) "Mothers of Soldiers in Wartime: a national news narrative", Critical Studies in Media Communication 24(5), pp. 429-445.

91. Thom, Douglas (1935) Everyday Problems of the Everyday Child New York: D. Appleton-Century Company Incorporated.

92. Thurer Shari L. (1994) The Myths of Motherhood: how culture reinvents the good mother, NY: Houghton Mifflin Company.

93. Tong, Rosemarie (1993) Feminine and Feminist Ethics, Belmont: Wadsworth Publishing Co.

94. Zeiger, Sara (1996) "She Didn't Raise Her Son to be a Slacker: motherhood, conscription, and the culture of the First World War", Feminist Studies 22(1), pp. 6-4.

\title{
About the Authors
}

\author{
Ana C. Gamer : : Associate Professor, Department of Journalism, \\ Marquette University, P.O. Box 1881, Milwaukee, WI \\ 53201-1881, USA. \\ E-mail: ana.garner@mu.edu \\ Phone: (414) 288-7383. \\ Karen Slattery : $\quad$ Associate Professor, Department of Broadcast \& \\ Electronic Communication, Marquette University, P.O. \\ Box 1881, Milwaukee, WI 53201-1881, USA. \\ E-mail: karen.s.lattery@rnu.edu \\ Phone: (414) 288-3490.
}


NOT THE PUBLISHED VERSION; this is the author's final, peer-reviewed manuscript. The published version may be accessed by following the link in the citation at the bottom of the page.

\section{Notes on Contributors}

Ana C. Garner is an associate professor in the Department of Journalism at Marquette University. Her research focuses on gender and popular culture. Recent publications include: Slattery, K. \& Garner, A. (2007) "Mothers of Soldiers in Wartime: A National News Narrative" Critical Studies in Media Communication 24(5), pp 429-445; Garner, A, Sterk, H. \& Adams, S. "Narrative Analysis of Sexual Etiquette in Teenage Magazines" Journal of Communication 48(4), pp. 59-78, Reprinted in Sonja K. Foss (2004) Rhetorical Criticism: Exploration \& Practice ( $3^{\text {rd }}$ ed.) Illinois: Waveland Press, Inc.

Karen Slattery is an associate professor in the Department of Broadcast and Electronic Communication at Marquette University. Her research focuses on media ethics, journalism history and gender issues. Recent publications include: Slattery, K. \& Garner, A. (2007) "Mothers of Soldiers in Wartime: A National News Narrative" Critical Studies in Media Communication 24(5), pp 429-445. She also writes a bimonthly ethics column for digitaljournalistorg.

Journalism Studies, Vol. 11, No. 2 (April 2010): pg. 143-157. DOI. This article is (C) Taylor \& Francis (Routledge) and permission has been granted for this version to appear in e-Publications@Marquette. Taylor \& Francis (Routledge) does not grant permission for this article to be further copied/distributed or hosted elsewhere without the express permission from Taylor \& Francis (Routledge). 